\title{
Position of Acting Land Acting Officer in Collecting Customs for Land and Building Rights (Study in Mataram City)
}

\author{
Rezha Yanuardi*, Minollah ${ }^{* *}$, Muhamad Ilwan ${ }^{* *}$ \\ *Postgraduate program Legal Study and Notaries, Mataram University, Indonesia \\ *** Lecture of Law Faculty Mataram University, Indonesia
}

\begin{abstract}
In carrying out its duties related to the making of deeds, the Land Deed Maker Officer (PPAT) is directly in contact with tax issues because the procedure for making a deed requires payment of taxes before the deed can be signed. According to the provisions in the collection of Customs and Land Rights (BPHTB) collection fees using a self-assessment system, but in the implementation of calculations and deposits to the regional treasury it is not often entrusted by the taxpayer to PPAT. The problems discussed in this study are about the implementation of BPHTB collection in the city of Mataram and how the position of PPAT in implementing BPHTB collection. This research is empirical legal research with the consideration of obtaining a direct description of the role of PPAT in implementing BPHTB collection in the city of Mataram. The approach used is the legislative approach, conceptual approach, sociological approach. Data collection techniques by conducting studies in the field in the form of interviews, then processing data and analyzed descriptively qualitatively so that answers to existing problems are obtained. Based on the results of the study it can be concluded that the implementation of BPHTB collection in Mataram City is still done conventionally, namely the taxpayer completes the Regional Tax Deposit Form - the Land Acquisition Fee (SSPD-BPHTB) and submits it manually to the Regional Finance Agency (BKD) of Mataram City to do the verification process, then the taxpayer makes a payment through the reception counter at the BKD Office in the City of Mataram. The position of PPAT in BPHTB collection is as an authorized official in fulfilling BPHTB services, the intention is that PPAT in carrying out its position as a public official authorized to make a transfer deed of land rights has the right to refuse a deed if it is not submitted proof of BPHTB payment.
\end{abstract}

Keyword: ppat, bphtb, self assessment system

\section{Introduction}

In the transfer of ownership rights, there are 2 types of taxes that must be paid by the parties, both buyers and sellers, namely the Cost of Acquiring Land and Building Rights (BPHTB) charged to the buyer and Income Tax (PPh) charged to the seller. BPHTB collection involves many related parties such as PPAT / Notary, District / City Government (Regional Revenue Service / Regional Personnel Agency) and Land Office, besides the regulations that support the implementation of BPHTB are also interrelated with each other.

Article 1 number 24 Government Regulation Number 24 of 1997 concerning Land Registration, states that Land Acting Officials (PPAT) are General Officials who are authorized to make certain land deeds. Furthermore, the PPAT position provisions are regulated in Government Regulation Number 37 of 1998 concerning Occupational Rules for Land Deed Officials, which states that Land Deed Officers are General Officials who are authorized to make authentic deeds regarding certain legal provisions regarding rights to land or property rights for apartment units.

Furthermore, it is necessary to emphasize that the PPAT referred to in this article is the PPAT Notary, considering that the District Head or BPN Officer / Land Office can also be a PPAT as stated in Article 5 of Government Regulation Number 37 of 1998 concerning Position Regulations for Land Deed Officials, 
stated that the Minister may appoint certain officials as PPAT, for example Camat as Temporary PPAT, and Head of Land Office / Land Office employee as Special PPAT.

In carrying out his position as a general official who is authorized to make deeds related to certain legal actions in the land sector, PPAT directly interacts with prospective taxpayers, in which the PPAT's duties and authorities are expected to assist local governments in increasing local tax revenues from the BPHTB sector. The interaction of PPAT with tax matters, especially BPHTB can be seen by the provisions of the procedure for signing the transfer of deed that requires proof of BPHTB payment by the taxpayer as referred to in Article 91 paragraph (1) of Law No. 28 of 2009 concerning Regional Taxes and Regional Retribution (PDRD Law) which in turn is also stipulated in Regional Regulations as implementing regulations.

Related to this, in Article 29 paragraph (1) of the City Regulation of Mataram Number 12 of 2010 concerning BPHTB which regulates the authorities authorized to fulfill BPHTB services, it is determined that "Officials of Land Deed / Notaries can only sign deeds of transfer of rights to land and / or building after the taxpayer submits proof of payment of tax".

From the provisions of Article 29 paragraph (1) of the City Regulation of Mataram City Number 12 of 2010 above, it can be understood that the authorized official is prohibited from exercising his authority if the taxpayer has not made the BPHTB payment owed. In addition, if PPAT violates the provisions contained in Article 29 paragraph (1) of the City Regulation of Mataram Number 12 of 2010, it will be subject to fines sanctions determined in Article 29 paragraph (4) of the City Regulation of Mataram Number 12 of 2010.

In the Elucidation of Article 96 paragraph (2) of the PDRD Law juncto Article 16 of the Mataram City Regulation Number 12 of 2010 it can be seen that the BPHTB collection system is self assessment, namely taxpayers are given the confidence to calculate, calculate, pay, and self-report the tax payable using the Letter Regional Tax Notification (SPTPD). This is reaffirmed in Article 3 paragraph (4) letter $h$ of Government Regulation Number 55 of 2016 that the type of regency / city tax is paid for itself based on calculations by taxpayers, one of which is BPHTB.

Self assessment system is a taxation system in which the initiative to fulfill tax obligations is in the taxpayer. ${ }^{1}$ To be able to increase tax revenue is not easy, because the self assessment system applied in Indonesia contains many weaknesses. One of them is very dependent on the honesty of the taxpayer. If the taxpayer is not honest, it is not easy for the tax officer to calculate the tax payable correctly.

The characteristics of the self assessment system are: ${ }^{2}$

a. Authority to determine the amount of tax payable is on the taxpayer himself;

b. Active taxpayers, starting from calculating, depositing and self-reporting tax payable;

c. The Fiscal did not interfere and only watched."

On the one hand, the efforts of the Local Government of the City of Mataram in increasing regional original income through BPHTB are certainly not easy, because the self assessment system implemented has many weaknesses, including the very dependent on honesty of taxpayers. But on the other hand there is a verification process for BPHTB SSPD conducted by the City of BKD Mataram, often perceived as an obstacle in the process of transferring rights to land and buildings, both by the taxpayer as the party charged with the obligation to pay and PPAT as the official who makes the deed transfer of rights.

As previously explained, the self-assessment system in BPHTB collection places taxpayers as an active party in the process of calculating and depositing BPHTB to the regional treasury, but different from the implementation level, taxpayers often entrust the calculation process and even deposit payments to the regional treasury to PPAT. Ideally BPHTB payments are carried out by the taxpayer or his proxy on the day and date of the transfer of deed signed before the PPAT, but usually due to a request for assistance from the client as a taxpayer, so that the PPAT concerned is willing to help calculate, filling in the Regional Tax Payment Form (SSPD) and the BPHTB payment process. This phenomenon causes the existence of PPAT in collecting BPHTB increasingly important. PPAT seems to be the main gate that influences BPHTB reception.

The author would like to further examine the position of PPAT in the implementation of BPHTB collection in the city of Mataram. This research was conducted to determine the suitability of existing regulations with their application in the community. In Article 91 paragraph (1) of Law Number 28 of 2009 concerning Regional Taxes and Regional Levies (PDRD Law) Juncto Article 29 paragraph (1) Regional Regulation

\footnotetext{
${ }^{1}$ Safri Nurmanu, Pengantar Perpajakan, Yayasan Obor Indonesia, Jakarta, 2003, p. 110.

${ }^{2}$ Y. Sri Pudyatmoko, Pengantar Hukum Pajak, Edisi IV, Andi Offset, Yogyakarta, 2009, p. 81.
} 
(Perda) of Mataram City Number 12 of 2010 concerning BPHTB determined that "Acting Officer Land / Notary can only sign the deed of transfer of rights to land and / or buildings after the taxpayer submits proof of payment of taxes ", the provision of course can affect the implementation of BPHTB collection that adheres to the self-assessment system. Based on the above, the author is interested in conducting research on the problem by formulating the title "Position of Officials of Land Deed Makers in Collecting Customs for Land and Building Rights".

\section{Research Method}

The type of study used in this paper is empirical juridical research, namely research conducted through observation of reality at the practical level associated with the ideal provisions contained in legislation, then an analysis of the gap that occurs between the two things, in this is concerning the implementation of BPHTB collection in relation to the procedure for making PPAT deeds and the PPAT position in the implementation of BPHTB collection in the city of Mataram. The approach used in answering the problem that has been formulated is by using a statute approach, through this approach the researcher will examine the laws and regulations related to the problems being studied. Sociological Approach (Sociological Approach), with this approach the researcher will analyze how reactions and interactions occur when a norm system works in society.

The type of data used in this study consisted of Primary Data obtained through direct research on related parties in the process of making Property Rights and Land Buy and Sell Deed and its relation to BPHTB calculation and payment, in this case the data obtained by conducting interviews with several PPAT in the city of Mataram as well as other related parties including officials or officers at the Regional Finance Agency of the City of Mataram. Secondary data, is data that is obtained indirectly, both in the form of library material and legislation.

\section{Discussion}

\section{Implementation of Collection of Fees for Acquisition of Land and Building Rights in the City of Mataram}

One source of potential tax that should be explored according to the economic situation and conditions as well as the development of national development today is the type of tax on the acquisition of land and building rights (BPHTB). ${ }^{3}$

Self assessment system as one of the tax collection systems has its own characteristics, namely the authority to determine the amount of tax on the taxpayer himself, where taxpayers are required to participate in the calculation, payment and reporting.

In the collection of BPHTB with the self assessment system in the city of Mataram in general it has been going well, however, it has not been fully implemented in accordance with the applicable legal provisions. Provisions regarding the tax base are the Tax Object Value, as stated in article 7 paragraph (2) Mataram City Regulation Number 12 of 2010, in Mataram City to use the Tax Object Value (NPOP) as the basis for calculating Land Acquisition Rights and Building (BPHTB) cannot be fully implemented.

Taxpayers tend to want a low value on taxes that are obligatory so that it triggers the emergence of an attempt to under assessment carried out by taxpayers. This is a driving factor for taxpayers to provide information about NPOP that is not in accordance with the actual acquisition value.

In accordance with the consensual principle that underlies the agreement law, the agreement was born since the agreement. For example, in a sale and purchase agreement, the parties agree that the goods and prices are the legal requirements of the agreement.

When the parties face the PPAT/Notary and submit information about the object of sale and purchase and the price they have agreed on, then the information submitted is what is considered to be the actual NPOP.

In the implementation of the BPHTB self-assessment system in the sale and purchase transactions in the city of Mataram, payments are made using SSPD BPHTB to the regional treasury through the payment counter provided at the Regional Personnel Agency (BKD) of Mataram City. Payment counters in the BKD of Mataram City are the only BPHTB payment places provided by the Mataram City government, because until

\footnotetext{
${ }^{3}$ Marihot P. Siahaan, Bea Perolehan Hak Atas Tanah dan Bangunan (Teori dan Praktek), Edisi Revisi, PT. Raja Grafindo Persada, Jakarta, 2005, p.6.
} 
now the City of Mataram BKD has not implemented payments with online facilities that are integrated with Bank NTB as Regional Banks.

Payments are made using the BPHTB SSPD form which consists of 5 (five) copies. As proof of the payment of the tax owed, the taxpayer will receive proof of deposit in the form of the first, third and fifth sheets of BPHTB SSPD. Of the three deposit proof sheets, the first sheet is for the taxpayer himself, while the third sheet is used to report the transfer of rights to the BKD and still must be equipped with other supporting files such as photocopies of certificates, identity and information from the District Office regarding the tax object, while the fifth sheet for submission of applications for registration of transfer of rights at the Land Office. The second and fourth sheets are archived by the BKD payment counter.

Based on observations made by the author, it is known that due to the verification process carried out by the BKD of Mataram City, the BPHTB collection system in the city of Mataram was not a pure Self Assessment system in accordance with the PDRD Act and Mataram City Regional Regulation Number 12 of 2010, but the Semi Self Assessment System or it can even be considered an Official Assessment System.

The amount of BPHTB value that must be paid depends on the results of verification carried out by the BKD. The transaction value stated on the BPHTB SSPD and the Deed is affected or must be in accordance with the verification results determined by the BKD, the taxpayer and PPAT must wait in advance for the verification results.

The verification results are the reference for the BPHTB value that the taxpayer must pay. When the previous calculations submitted by the taxpayer or PPAT through SSPD BPHTB are lower than the provisions of the verification results, the verifier will issue the disposition of the proposed BPHTB SSPD and return it to PPAT for adjustment. The value stated on the Deed must also be in accordance with the NPOP as outlined in the BPHTB SSPD.

If BPHTB collection is done purely according to the Self Assessment System, then actually the taxpayer is in an active position and has the right to do the calculation and determination of the amount of BPHTB value owed while still using the predetermined calculation formula without intervention from BKD as the tax authorities.

The results of the BPHTB value verification used by the BKD of Mataram City are using estimates of market value. Market value is obtained from the results of the average value of the latest transfer of rights in the surrounding area adjacent to the tax object.

The outstanding BPHTB value paid by pure taxpayers is determined by the BKD of Mataram City, the calculation of BPHTB carried out by taxpayers or PPAT in accordance with the agreement can be annulled by BKD which with verification, NPOP can change according to BKD analysis results based on estimated market prices, except if the value of the calculation of the taxpayer or PPAT is considered to have been in accordance with or above the BKD analysis value, the BPHTB value submitted can be immediately approved.

\section{Position of Land Deed Officer in the Implementation of Collection of Customs for Land and Building Rights}

In providing services to the public, the government has provided certain institutional instruments in accordance with their respective main tasks and functions and authorities which among them are interrelated but also share the same goal of providing the best service and service to the community.

In the context of the Cost of Obtaining Land and Building Rights (BPHTB), there are 4 (four) institutional elements, each of which has different duties and functions as well as authorities that are different from each other but are closely related to the implementation of their basic tasks and functions.

The National Land Agency (BPN) as the government agency that carries out the management function of administrative matters related to land has a close relationship with the district / city government in this case the Regional Financial Agency (BKD) as the BPHTB management agency which is one type of regional tax and Acting Land Deed Officer (PPAT) as the authorized official in making the deed of transfer of land rights, as well as the State Auction Officer.

The linkage can be simply described through one example, for example in a legal action relating to the transfer of land and building rights required by the deed of the Land Deed Maker as the basis for registering the transfer of rights at BPN as the land administration agency, but there is a predetermined procedure in legislation that affects the implementation of PPAT duties in carrying out its authority in making land 
certificates, namely the provision that PPAT can only sign a deed of transfer of land rights if the taxpayer has submitted proof of BPHTB tax payments, besides that PPAT is also required to report deeds made to the regional government in this case BKD as the tax authorities, these provisions are accompanied by the threat of fines for PPAT violating them.

Overall, the parties related to collecting BPHTB are as follows:

1. Recipient of rights, as a taxpayer;

2. PPAT / Notary, as the Officer who is given the authority to make the transfer of rights deed;

3. The Auction Officer, who is authorized to make auction minutes;

4. Regional Finance Agency, as the agency authorized to issue the United Nations Tax Return (SPPT);

5. In this case the BPN is the Regency / City Land Office, as the agency that processes the application for registration of transfer of rights.

Notary / PPAT, Auction Officer and Head of Land Office have the right and must refuse to sign the deed of rights / minutes of auction / rights registration if the BPHTB payment obligation has not been paid. The date contained in the deed of transfer rights / minutes of auction / registration of rights must be after or at least equal to the date of payment stated in the BPHTB SSPD.

The existence of these officials has a large influence in relation to the effort to collect BPHTB. Its position as an executive officer in the rights transition activities that guarantees legal certainty turns out its existence is very helpful for the tax authorities in an effort to fulfill BPHTB. PPAT's authority to reject the signing of the deed of transfer of rights greatly affected the increase in regional revenues from the BPHTB Regional Tax sector, although none of the articles in PP No. 37 of 1998 concerning PPAT Position Regulations regulated or ordered PPAT to collect taxes.

PPAT has a dignified and independent position, not under the authority of any other official. PPAT is not subject to other positions so that it can be said that PPAT cannot be governed or prohibited in carrying out its duties by anyone except only subject to the laws and regulations.

In implementing the PPAT function, in general there are no provisions governing who is authorized to govern it, or it can be understood that according to its function PPAT is not responsible to anyone. But in relation to the appointment and dismissal decisions, PPAT administratively remains accountable to the government that appoints it. PPAT accountability is only in the form of legal liability according to court decisions when there are problems in the civil or criminal domain involving PPAT, while in the professional PPAT scope the organization is professionally responsible in the event of ethical violations according to the Code of Ethics of the Land Deed Making Official.

With regard to matters relating to the position of PPAT position as General Officials, it is regulated in Government Regulation No. 37 of 1998 concerning PPAT Position Regulations and its implementation rules are regulated in Agrarian State Minister Regulation / Head of National Land Agency Number 4 of 1998 concerning Implementation of Government Regulation Number 371998

According to the provisions of Article 2 paragraph (2) Government Regulation Number 37 of 1998, certain legal actions related to the making of deeds that are within the scope of the authority of PPAT are:
a. buy and sell;
b. exchange;
c. grant;
d. income into the company (inbreng);
e. shared rights;
f. granting of building use rights / use rights to property rights;
g. granting of mortgages;
h. power of attorney imposes mortgages.

In carrying out the PPAT position there is a fairly close relationship with taxation, this is due to the authority of PPAT as an authorized official to make deeds relating to land directly in contact with taxes, where in every legal act or legal event concerning land and or buildings there are tax obligations for the parties that carry out legal acts or are associated with a legal event concerning land and building rights.

In its position as a public official who is a partner of government work, besides the deed he made has legal consequences, in the implementation of his duties PPAT is also expected to play a role in securing regional 
revenues through BPHTB fulfillment services, this can clearly be seen from the purpose of article 29 paragraph (1) Regional City of Mataram in 2010.

There is a typical legal relationship between PPAT and the parties, including the relationship does not require the existence of an agreement or the power of attorney to make deeds or to perform certain jobs, PPAT products in the form of deeds based on the authority of PPAT originating from requests or desires the party itself and the PPAT are not parties to the deed in question.

In relation to the BPHTB tax collection effort, PPAT was actually not a tax official and as a dignified position that was not properly required to carry out part of the duties of the tax officer, the government had its own apparatus for the task. In a legal act or legal event regarding the transfer of land rights, PPAT does not have the right to regulate the agreement on transaction value or acquisition value, but as a consultant or official who is considered to have certain competencies and is considered more understanding about tax calculation, taxpayers are often entrust the tax management to PPAT, both regarding the calculation and payment to the regional treasury, in this case it is expected that PPAT should not participate or participate in advocating in setting prices agreed upon by the parties.

In the Full Self-Assessment, the process and the right to set are already on the Taxpayer. This process and the right to set is realized in filling out the SSPD properly and correctly then paying for itself at the Payment Counter provided on the BKD.

In the provisions of Article 4 paragraph (4) letter h of Government Regulation Number 55 of 2016 concerning General Provisions and Procedures for Regional Taxation, it is determined that BPHTB includes the type of district / city tax that is self-paid based on taxpayer calculations, in accordance with the provisions in Article 16 paragraph 3 of Mataram City Regulation Number 12 of 2010 concerning Fees for Acquisition of Land and Building Rights states that the BPHTB SSPD must be filled in clearly, correctly and completely and signed by the taxpayer or proxy. But in reality, many taxpayers do not bother to calculate the amount of tax payable, they submit to other parties, namely to PPAT.

The parties that make the transfer of rights always want convenience in their affairs including not wanting to be bothered with the issue of tax processing. In general, they want to come to PPAT once and all their affairs can be resolved, especially if the client is domiciled outside the city of Mataram.

Requests for assistance from clients to PPAT are not only limited to calculating the value of their tax obligations, but also at the same time depositing payments. Custody of tax payments is made only based on the trust of the taxpayer to PPAT and without the existence of a power of attorney. ${ }^{4}$

As a government partner who is in the forefront of PPAT, it is required to apply the principle of prudence, honesty and have a high sense of responsibility, which is expected to assess the fairness of the value of a land so that it can educate taxpayers in fulfilling their obligations.

With the existence of tax obligations that involve PPAT in the procedures for carrying out their duties, PPAT responsibilities become increasingly severe because this relates to sanctions given by law in the event that the PPAT is negligent in carrying out its duties to make deeds which in the implementation of its duties are bound by procedures certain regulated in the laws and regulations, wherein the procedure relates to the fulfillment of BPHTB services so that it appears as if PPAT acts as an intermediary between the tax authorities and taxpayers, even though PPAT's position is not at all part of the tax authorities.

The threat of sanctions in the implementation of an obligation illustrates that a person can be forced to carry out his duties and functions properly so as to stimulate the existence of a person's role in the realization of certain goals desired by the Laws and Regulations.

In collecting BPHTB using the PPAT self-assessment system the position of PPAT is as a passive and active party should be a client as a taxpayer. But in reality PPAT in carrying out its duties is required to play an active role in socialization/education regarding BPHTB and legal advice to clients who come, more than that, according to information it is known that taxpayers often request PPAT assistance to regulate the amount of NPOP to be poured in SSPD BPHTB according to the wishes and interests of the client to be adjusted to the estimated value which would be approved by the tax authorities. As an illustration, for example in a sale and purchase transaction, PPAT is in a very dilemmatic position, on the one hand PPAT has stated about the existence of the parties' tax obligations including the percentage / tax rate and the basis

${ }^{4}$ Muhammad Ali, SH.,M.Kn., PPAT di Kota Mataram, Interview on February 19, 2019. 
of the calculation, the transaction value, but after getting an explanation, many parties feel that the value to be paid is too large so they ask that the actual transaction value is not stated in the BPHTB SSPD. ${ }^{5}$

From the description of the practice as exemplified above, it is clear that PPAT is indeed in a very dilemmatic position, on the one hand PPAT has tried to enforce the rules and carry out existing procedures by requiring the payment of BPHTB before being able to carry out its duties, but on the other hand if PPAT rigid in responding to the rules and ignoring the wishes of the client, it is feared the client will discourage him from using the services of the PPAT concerned. In these conditions, PPAT is required to be able to find solutions to be able to accommodate the wishes of the client but without overriding the existing rules.

In a land rights transitional transaction, PPAT only applies legal actions taken by the parties into the BPHTB Deed and SSPD, then PPAT calculates the BPHTB value owed for transactions carried out by the parties according to the formula specified in the PDRD Law or the Mataram City Regional Regulation Number 12 of 2010.

According to Article 29 paragraph (1) of the Regional Regulation of Mataram City Number 12 of 2010, the Acting Officer of the Land / Notary can only sign the deed of transfer of rights to land and / or buildings after the taxpayer submits proof of payment of tax. These provisions indirectly provide a control function to PPAT / Notaries on compliance with BPHTB compliance.

The control function provided by Article 29 paragraph (1) of the Regional Regulation of Mataram City Number 12 of 2010 turns out only to the taxpayer's compliance not to the correctness of data filling in the SSPD form. In the provision does not give authority to PPAT to control the price of transactions listed in the SSPD form precisely from the provisions it can be interpreted that the contents of the transfer of deed regarding the transaction price is adjusted by filling in the SSPD by the taxpayer, where the data listed on the SSPD is the reference data in making deed of transfer of rights. Regarding the price of a pure transaction determined by the agreement of the parties, PPAT only constricts the wishes of the parties in the deed made.

The existence of certain situations and conditions in the transfer of land rights sometimes forces PPAT to improvise in implementing procedures for making deeds with the aim of effectiveness so that the process of transferring land rights is not hampered and as a form of excellent service to clients.

In this case PPAT is faced with 2 (two) heavy choices, on the one hand PPAT wants to provide the best service by helping one of the problems of the client who becomes a taxpayer while on the other hand the PPAT must constrict the client's actions in a deed correctly and to then report the deeds made to the regional government (BKD) even though PPAT is actually not a tax officer.

Basically the PPAT product certificate is classified as a Partij deed, where PPAT is actually in a passive position and only expresses the wishes of the parties facing the deed based on the document submitted and according to the statement and agreement of the parties delivered before him, or in other words PPAT only record and legitimize legal actions or legal events that occur relating to land and building rights.

In this case the authority of PPAT is limited in the formal domain, and has absolutely no obligation and even the authority to enter into the material domain, namely finding out the truth of the data conveyed by the client as long as he has shown evidence, so that the values agreed upon by the parties are poured in the SSPD BPHTB and into the deed must be proven by the existence of a receipt (receipt).

The role of PPAT which seems to be an active party in collecting BPHTB is nothing but simply because of requests for assistance from clients as taxpayers, where in this case the position of PPAT is only limited to representing its clients.

\section{Conclusion}

The collection of BPHTB collection in Mataram City is still done conventionally, namely the taxpayer completes the Regional Tax Payment Form - the Land Acquisition Fee (BKP) and the Regional Finance Agency (BKD) submissions of Mataram City for verification, and then taxpayers make payments through the BKD Office in the city of Mataram. The BKD Mataram City applies a verification process which includes research activities. The calculation of BPHTB is carried out by taxpayers or PPAT, which with the verification; NPOP can change according to the results of BKD analysis conducted based on estimated market prices.

The position of PPAT in BPHTB collection is an official fulfilling BPHTB service, the purpose is to carry out its position as a public official to make the transfer of land rights has the right to use a certificate if

${ }^{5}$ Hamzan Wahyudi, SH.,M.Kn., PPAT di Kota Mataram, Interview on February 19, 2019. 
it is not submitted proof of BPHTB payment (SSPD-BPHTB validated) concerning Article 39 of the Government concerning the Land Registration Certificate in conjunction with article 29 paragraph (1) of the Regional Regulation of Mataram City Number 12 of 2010 concerning Fees for Acquisition of Land and Building Rights. PPAT 's position is only limited to increasing tax compliance and encouraging order tax, the linkage of PPAT with BPHTB is limited to the procedure for signing a deed that requires BPHTB to be paid.

\section{References}

[1] Adrian Sutedi, 2010, Peralihan Hak Atas Tanah dan Pendaftarannya, Sinar Grafika, Jakarta.

[2] Department of Education and Culture, 1989, Kamus Besar Bahasa Indonesia, Balai Pustaka, Jakarta.

[3] Marihot P. Siahaan,2005, Bea Perolehan Hak Atas Tanah dan Bangunan (Teori dan Praktek), Edisi Revisi, PT. Raja Grafindo Persada, Jakarta.

[4] ...................., 2010, Kompilasi Peraturan Di Bidang BPHTB, Panduan Dalam Penyusunan Aturan Pelaksanaan Peraturan Daerah Tentang BPHTB, Graha Ilmu, Yogyakarta.

[5] Muhammad Yamin dan Rahim Lubis, 2004, Beberapa Masalah Aktual Hukum Agraria, Pustaka Bangsa Press, Medan.

[6] Philipus M. Hadjon, dkk., 2002, Pengantar Hukum Administrasi Indonesia, Gadjah Mada University Press, Yogyakarta.

[7] R. Santoso Brotodihardjo, 2013, Pengantar Ilmu Hukum Pajak, PT. Refika Aditama, Bandung.

[8] Safri Nurmanu, 2003, Pengantar Perpajakan, Yayasan Obor Indonesia, Jakarta.

[9] Suparnyo, 2012, Hukum Pajak Suatu Sketsa Asas, Publisher Pustaka Magister, Semarang.

[10] Urip Santoso, 2016, Pejabat Pembuat Akta Tanah, Perspektif Regulasi, Wewenang dan Sifat Akta, Prenadamedia Group, Jakarta.

[11] Y. Sri Pudyatmoko, 2009, Pengantar Hukum Pajak, Edition IV, Andi Offset, Yogyakarta. 